Bull. Fac. Agric., Cairo Univ., 71: 307-315(2020)

\title{
PRODUCTION OF SAFE AND HEALTHY PRETZELS
}

(Received: 28.10.2020)

\author{
By \\ Ashgan M. Aly and Hoda H. Hafez \\ Department of Bread and Pasta Research, Food Technology Research Institute, \\ Agricultural Research Center, Giza, Egypt.
}

\begin{abstract}
Pretzels product is very popular snack food for different age stage specially children. The effect of different alkali caustic solutions, substituting wheat flour (ex. rate $72 \%$ ) with corn and rice flour at (50:50) percentage and addition of three spices (turmeric $2 \%$, paprika $2 \%$, and chili $1.5 \%$ ) on $\mathrm{pH}$, mineral content, chemical composition, sensory evaluation, texture and water activity as storage quality of product, percentage of the recommended dietary allowances (RDA\%), and economic pretzel cost were examined. The $\mathrm{KOH}(1.5 \%)$ as caustic solution was preferred for cooking step at $\mathrm{pH}$ and mineral content. While a typically $\mathrm{pH}$ recorded for pretzels treated with $\mathrm{KOH}$ was approximate 7 for dough, which decrease by baking to around $\mathrm{pH}$ 5. Sensory evaluation showed that the control and rice turmeric had the highest value for overall score. Chemical composition recorded significant values for protein ranging the from 3.01 to 3.86. Ash, fat and calories had the highest value in corn paprika pretzels. Also $\mathrm{KOH}$ solution had a good effect on pretzels quality (color, texture). Additional $\mathrm{KOH}$ as caustic solution had good effect on mineral content for all samples especial $\mathrm{K}$ content. $\mathrm{Mg}$ and $\mathrm{Ca}$ were high in corn and rice paprika pretzels. The keeping quality for pretzels indicated there was no high change in value (texture, water activity $\mathrm{a}_{\mathrm{W}}$ ) during storage periods for 3 months. The percentage of the recommended dietary allowances (RDA \%) are provided from $100 \mathrm{~g}$ of product for children (710) years indicated that all samples provide body with $10-12 \%$ protein, $20 \%$ calories, $20-24 \%$ of Fe, $8-18 \%$ of $\mathrm{Ca}$ and $29-63 \%$ of $\mathrm{Mg}$. The cost of pretzels ranged between 2.50 and $3 \mathrm{~L}$. E. $/ 100 \mathrm{~g}$ This study indicated that corn and rice pretzels treated with $\mathrm{KOH}$ solution were healthy functional snacks with low input cost.
\end{abstract}

Key words: Pretzels; different caustic solutions; spices; parameter quality.

\section{INTRODUCTION}

Pretzels are acknowledged as a healthy snack and are gaining popularity around the world. The pretzel production process includes dough mixing, forming/shaping using an extruder at low pressure, cooking in a hot alkali solution, and baking. The baking process is divided into two steps: (1) first rapid baking at high temperature and (2) a slower, and lower temperature for drying to reduce moisture content to $<4 \%$ (Seetharaman, 2014). Pretzel represents a major, growing portion of snack worldwide. The sales in the United States alone exceed 1-2 billion in 2001(Seetharaman et al., 2002). Research on pretzels is particularly lacking with respect to the properties of raw materials or processing parameters that influence final product qualities from the perspective of consumers. Practically, no research has been done in these areas since hard pretzels were introduced into America in hard pretzel manufacturing, including processing methods (Rooney and Rooney, 2001).

Sodium is used as $\mathrm{NaCl}$ and $\mathrm{NaOH}$ in different steps for processing pretzels. Sodium can be bad for health. According to the Dietary Guidelines for Americans, diets higher in sodium are associated with an increased risk of developing high blood pressure and increased risk of hypertension and related cardiovascular diseases. This situation led to a trend of Dietary sodium intake (DSI) reduction by decreasing the use of common salt $(\mathrm{NaCl})$ in the regular diet and/or by increasing dietary potassium intake (DPI). Most children and adults consume too much sodium, as the major component of salt in foods they eat. Foods high in sodium include processed and convenience foods, processed meat, soups, and some snack foods. This was the reason why the World Health Organization 
(WHO) issued a "strong recommendation" about the upper sodium intake which was set at 2.0 $\mathrm{g} / \mathrm{d}$, which is equivalent to $5.0 \mathrm{~g} / \mathrm{d}$ of salt $(\mathrm{NaCl})$ (WHO, 2012a). The Daily Value (DV) for sodium is less than 2,300 milligrams (mg) per day, the Daily Value (DV) for potassium is $4,700 \mathrm{mg}$ per day. Its is recommended to use the Nutrition Facts label to compare and choose foods to get $100 \%$ DV of potassium on most days (WHO, 2012b).

Maize (Zea mays) is rich in energy and good quality protein, the pericarp fraction contains 77.7- 84.6\% dietary fiber (Cho et al., 2014). Also, Rice (Oryza sativa) is the second cereal crop in Egypt after wheat (Abdelaal and Thimany, 2019). These are good sources of pretzels (Paykary et al., 2016). Doweidar, (2006) reported that chemical composition of white rice and corn flour contains 7.72 and 8.49 protein, 90.74 and 87.01 carbohydrate, 0.68 and 2.14 fat, 0.48 and 1.20 crude fiber, and 0.38 and 1.16 ash, respectively.

Curcuma or turmeric (Curcuma longa L.) is a rhizomatous monocytyledonous perennial herbaceous member of the ginger family (Zingibera). Curcuma contains $60-70 \%$ carbohydrate, $8.6 \%$ protein, $5-10 \%$, fat, $7 \%$ fiber, $3-5 \%$, curcumoid $(50-70 \%$ curcummin, as active component in turmeric) and up to $5 \%$ essential oil and resins (Goel and Aggarwal, 2010).

Red peppers (Capsicum annuиm L.) are one of the most important spices, widely cultivated and used all over the world. This crop is widely consumed as fresh vegetable or condiment and used for pharmaceutical and cosmetic purposes. The amounts and characteristics of flavoring, coloring and especially pungent principles of Capsicum fruits are important quality parameters. Their strong pungency has been attributed to capsaicinoids, of which capsaicin and dihydrocapsaicin constitute more than $80 \%$ (Giuffrida et al., 2013). Furthermore, red pepper is an excellent source of ascorbic acid and polyphenols, particularly flavonoids, quercetin and luteolin. Thus, all the mentioned compounds show antioxidant activity as potential action against certain cancers, stimulate the immune system, prevent cardiovascular diseases and delay the aging process, amongst other biological activities (Guil-Guerrero et al., 2006). In fact, large red bell pepper contains over $300 \%$ of the daily value (DV) for this nutrient (Chuah et al., 2008). Cepanec et al., (2017) reported that the application of spices or herbs, their extracts, and various vegetables as taste improvers in potassium chloride $(\mathrm{KCl})$-based salt substitutes is not a new idea. Among them, many common seasoning herbs, their extracts, as well as vegetables in finely milled powderous form have been used: (i): Seasoning herbs: turmeric (Curcuma longa L.); (ii) Vegetables: red capsicum and chili pepper (Capsicum annuum L.); and (iii) Miscellaneous mixtures of these ingredients.

The present study aimed to produce functional pretzels by using $\mathrm{KOH}$ caustic solution as alternative alkali solution instead of $\mathrm{NaOH}$ solution. Corn, rice flour and different spices i.e turmeric, paprika and chill were used to produce healthy pretzels formula and pretzels products were evaluated chemically, organoliptically and economically.

\section{MATERIAL AND METHODS}

2.1. Materials

Wheat flour (Triticum aestivom L.) (72\%) extraction rate was obtained from Al-SalamCompany for Milling and Baking, Cairo, Egypt. Baking Ingredients: yeast, sugar, corn starch, corn oil, corn flour (Zea mays), rice flour (Oryza sativa), red capsicum (paprika) and chili pepper (Capsicum annuum L.), turmeric (Curcuma longa L.) and salt were obtained from the local market Giza, Egypt.

- All chemicals used in the experiment were of analytical grade.

\subsection{Methods}

\subsubsection{Preparation of samples}

Preparation of six blends from corn and rice flour were mixed with wheat flour (ex. rate $72 \%$ ) at percentage of $50: 50 \%$, and adding for blend separately $2 \%$ turmeric or $2 \%$ paprika or $1.5 \%$ chili. The formulas of the blends used for production pretzels are shown in Table (1).

\subsubsection{Preparation of caustic solution}

Three solutions were prepared as caustic solutions of $\mathrm{NaOH}(1 \%)$; $\mathrm{KOH}(1.5 \%)$; and $\mathrm{CaCO}_{3}(2 \%)$.

\subsubsection{Production of pretzels}

Pretzel samples were produced according to Seetharaman et al. (2004) method as follows:

Flour (100g), fat (20g), sugar (one g), yeast (one $\mathrm{g}$ ), turmeric $(2 \mathrm{~g})$ or paprika $(2 \mathrm{~g})$ or chili $(1.5 \mathrm{~g})$ separately and salt (one $\mathrm{g}$ ) were mixed for one min. The water (50\% flour basis) was added and remixed for $4 \mathrm{~min}$ to form dough. The dough was left to rest for $20 \mathrm{~min}$ then shaped. The shaped pretzel passed through a dipping solution ( $1 \%$ sodium hydroxide or $1.5 \%$ potassium 
Table (1): Formulas of blends of corn/ rice used for the production of pretzels.

\begin{tabular}{|c|c|c|c||c|c|c||c|}
\hline \multirow{2}{*}{ Ingredients } & \multicolumn{3}{|c|}{ Corn blend (g/100g) } & \multicolumn{3}{c||}{ Rice blend (g/100g) } & \multicolumn{1}{c|}{$\begin{array}{c}\text { Control } \\
\text { blend }\end{array}$} \\
\cline { 2 - 8 } & $\mathbf{C 1}$ & $\mathbf{C 2}$ & $\mathbf{C 3}$ & $\mathbf{R 1}$ & $\mathbf{R 2}$ & $\mathbf{R 3}$ & $\mathbf{5}$ \\
\hline Corn/Rice flour & $\mathbf{5 0}$ & $\mathbf{5 0}$ & $\mathbf{5 0}$ & $\mathbf{5 0}$ & $\mathbf{5 0}$ & $\mathbf{5 0}$ & - \\
\hline Wheat flour & $\mathbf{5 0}$ & $\mathbf{5 0}$ & $\mathbf{5 0}$ & $\mathbf{5 0}$ & $\mathbf{5 0}$ & $\mathbf{5 0}$ & $\mathbf{1 0 0}$ \\
\hline Yeast & $\mathbf{1}$ & $\mathbf{1}$ & $\mathbf{1}$ & $\mathbf{1}$ & $\mathbf{1}$ & $\mathbf{1}$ & $\mathbf{1}$ \\
\hline Sugar & 1 & 1 & 1 & 1 & 1 & 1 & 1 \\
\hline Oil & $\mathbf{2 0}$ & $\mathbf{2 0}$ & $\mathbf{2 0}$ & $\mathbf{2 0}$ & $\mathbf{2 0}$ & $\mathbf{2 0}$ & $\mathbf{2 0}$ \\
\hline Salt & 1 & 1 & 1 & 1 & 1 & 1 & 1 \\
\hline Turmeric powder & $\mathbf{2}$ & - & - & $\mathbf{2}$ & - & - & - \\
\hline Paprika powder & - & $\mathbf{2}$ & - & - & $\mathbf{2}$ & - & - \\
\hline Chili powder & - & - & $\mathbf{1 . 5}$ & - & - & $\mathbf{1 . 5}$ & - \\
\hline Water & $\mathbf{5 2}$ & $\mathbf{5 2}$ & $\mathbf{5 1}$ & $\mathbf{5 2}$ & $\mathbf{5 2}$ & $\mathbf{5 1}$ & $\mathbf{5 0}$ \\
\hline
\end{tabular}

hydroxide or $2 \%$ sodium carbonate separately) at $95 \stackrel{\mathrm{C}}{ }$ for $10-15 \mathrm{sec}$. the produced pretzel was

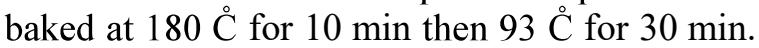
The prepared pretzels were cooled and then packed in polyethylene bags until further analysis and storage for 3 months.

2.2.4. Proximate analysis: Moisture, protein, fat, crude fiber, and ash contents of the raw materials and treatments were determined according to the methods of AOAC (2005). Determination of total carbohydrates was calculated by difference.

2.2.5. Determination of minerals: Minerals contents ( $\mathrm{Na}, \mathrm{K}, \mathrm{Ca}, \mathrm{Mg}, \mathrm{Zn}$, and $\mathrm{Fe}$ ) were determined using methods of AOAC (2005). Perkin Elmer (Model 3300, USA) Atomic Absorption Spectrophotometer was used to determine these minerals.

2.2.6. Sensory evaluation: Different treatments of produced pretzel were organoleptically evaluated for general appearance, color, crispiness, flavor and overall score by using 10 panelists according to the method of Khan and Nowsad (2012).

2.2.7. Determination of water activity (aw): The water activity was measured with a Rotronic (model Hygrolab3 made in Switzerland). The ground sample of pretzels in zero time and during storage periods ( 3 months) was filled in the plastic cups approach the top and the Hygroplam probe was inserted in these cups. After almost three to four minutes the display showed the water activity reading, along with temperature (Piga et al., 2005).

2.2.8. Texture analysis: Texture analyzer (Brookfield CT3 No. M08-372-C0113, USA) was used to measure the texture profile of pretzels at zero time and during storage in terms of hardness $(\mathrm{N})$, adhesiveness (mj) of the samples according to the method described by Meullenet et al., (1998).

2.2.9.Determination of $\mathbf{p H}$ : The $\mathrm{pH}$ was measured using a $\mathrm{pH}$ meter (Hanna Instruments, FC200B, USA).

\subsubsection{The economical evaluation of pretzels}

The economic cost of pretzels were calculated for the raw materials (corn flour, rice flour, ete...) price and production cost.

\subsubsection{Statistical analysis}

The Data were analyzed using CoStat, version 3.03 for personal computers according to Ott, (1988). The tests used ANOVA test and descriptive statistics test. A treatment effect was assumed to be statistically significant at $\mathrm{P}<0.05$

\section{RESULTS AND DISCUSSION}

\subsection{Effect of different caustic solution on minerals content}

The effect of different caustic solutions $\left(\mathrm{NaOH}, \mathrm{KOH}\right.$, and $\left.\mathrm{CaCO}_{3}\right)$ as treatment for pretzel on minerals content of control pretzel sample (wheat flour 100\%) are shown in Table (2).

Table (2): Effect of different caustic solutions on minerals content of control pretzel (mg/100g).

\begin{tabular}{|c|c|c|c|c|c|c|}
\hline Sample & Na & K & Ca & Mg & Zn & Fe \\
\hline $\mathbf{1}$ & 651.33 & 200.29 & 59.78 & 65.33 & 2.06 & 1.19 \\
\hline $\mathbf{2}$ & 513.73 & 328.43 & 61.28 & 57.06 & 2.14 & 1.82 \\
\hline $\mathbf{3}$ & 612.15 & 140.89 & 133.37 & 65.97 & 2.6 & 1.29 \\
\hline \multicolumn{6}{|c}{ caustic solution with 1) NaOH; 2) KOH; and 3) $\mathbf{C a C O}_{3}$} \\
\hline
\end{tabular}

Sodium is essential for cellular homeostasis and physiological function. Excess dietary sodium has been linked to elevations in blood pressure (BP). Salt sensitivity of BP varies widely, but certain subgroups tend to be more salt sensitive. The mechanisms underlying sodium-induced increases in BP are not completely understood but may involve 
alterations in renal function, fluid volume, fluidregulatory hormones, the vasculature, cardiac function, and the autonomic nervous system. Recent pre-clinical and clinical data support that even in the absence of an increase in BP, excess dietary sodium can adversely affect target organs, including the blood vessels, heart, kidneys, and brain (Farquhar et al., 2015). Table (2) shows that sample 1 was the highest in $\mathrm{Na}$ content $(651.33 \mathrm{mg} / 100 \mathrm{~g})$ which used sodium hydroxide as caustic solution in pretzel production. The high sodium content in diet may be due to increase elevate the blood pressure as mentioned by Farquhar et al. (2015). Thus KOH was pre ferd as the caustic solution (sample 2) in the following pretzel producing as shown later which was the lowest content of sodium (513.73 $\mathrm{mg} / 100 \mathrm{~g}$ ). Calcium is the main source of the building blocks of bones and teeth. The data show that, calcium content was high in sample 3 which was treated with $\mathrm{CaCO} 3$ solution as a source of calcium, then sample 2. Sample 1 was the lowest sample in calcium content. Zinc and magnesium are essential for normal growth, development of the immune response and participating as a factor for more than 300 enzymes (Salgueiro et al., 2002). Data in Table (2) show that $\mathrm{Zn}$ and $\mathrm{Mg}$ increased in sample 3 as a result of raw material in that samples. Iron has several vital functions in the body, it serves as a carrier of oxygen to the tissues, as a transport medium for electrons within cells and as an integrated part of important enzyme system in various tissues (FAO/WHO, 2004). The data in Table (2) revealed that $\mathrm{Fe}$ content was high in sample $2(1.82 \mathrm{mg} / 100 \mathrm{~g})$ containing $\mathrm{KOH}$ solution, then sample $3(1.29 \mathrm{mg} / 100 \mathrm{~g})$ and sample $1(1.19 \mathrm{mg} / 100 \mathrm{~g})$.

\subsection{Effect of different caustic solutions on the pH of pretzel dough and after baking}

Table (3) shows the effect of different caustic solutions on $\mathrm{pH}$ of pretzel dough and

Table (3): Effect of different caustic solutions on pH of pretzel dough and after baking of the control pretzel.

\begin{tabular}{|c|c|c|}
\hline sample & pH in dough & pH in product \\
\hline $\mathbf{1}$ & $8.2 \mathrm{a} \pm 0.01$ & $5.97 \mathrm{~b} \pm 0.02$ \\
\hline $\mathbf{2}$ & $7.11 \mathrm{c} \pm 0.05$ & $5.32 \mathrm{c} \pm 0.04$ \\
\hline $\mathbf{3}$ & $7.68 \mathrm{~b} \pm 0.03$ & $6.36 \mathrm{a} \pm 0.14$ \\
\hline L.S.D(0.05) & $\mathbf{0 . 0 6}$ & $\mathbf{0 . 1 3}$ \\
\hline $\begin{array}{l}\text { Control with caustic solution } \\
\text { 1) NaOH; 2) KOH; and 3) } \mathrm{CaCO}_{3}\end{array}$
\end{tabular}

Means in the same column with different letters are significantly different $(p \leq 0.05)$.

Each mean value is followed by \pm SE (standard error). after baking of the control pretzel sample (100\% wheat). The data indicated that treatment with $\mathrm{NaOH}$ as caustic solution had the highest value of $\mathrm{pH}$ for dough (8.2), while treatment with $\mathrm{KOH}$ as caustic solution had the lowest value of $\mathrm{pH}$ for dough and after baking (7.11\& 5.32). Meanwhile, treatment with $\mathrm{CaCO} 3$ had the highest value of $\mathrm{pH}$ for sample after baking (6.36). This may be due to the used $\mathrm{NaOH}$ as caustic solution increased $\mathrm{pH}$ in dough and final product. This result agrees with West and Christopher, (2002) who reported that the surface $\mathrm{pH}$ on a traditionally made soft pretzel is alkaline because of a necessary caustic bath or cook step.

\subsection{Effect of $\mathrm{KOH}$ as a Caustic solution on} $\mathrm{pH}$ of pretzel dough and after baking of rice and corn blends

The effect of $\mathrm{KOH}$ as a caustic solution on $\mathrm{pH}$ of pretzel dough and products from rice and corn blends with wheat flour at percentage (50\%: 50\%) are shown in Table (4).

From Table (4) it could be concluded that all dough samples were around $\mathrm{pH} \mathrm{7,} \mathrm{while} \mathrm{the}$ sample 2 recorded the highest value of $\mathrm{pH}$ (7.16), and the lowest value of $\mathrm{pH}$ in dough was 6.59 for sample 4 . Whereas the highest $\mathrm{pH}$ value of products (after baking) was 5.44 in sample 4 . However, the lowest value of $\mathrm{pH}$ was 5.25 for sample 5. From the above results, it could be concluded that corn flour acompanied by turmeric had alkalized effect when $\mathrm{KOH}$ used was as caustic solution for dough, while decreased $\mathrm{pH}$ in the final product may be due to

Table (4): Effect of KOH as a Caustic solution on the pH of pretzel dough and after baking.

\begin{tabular}{|c|l|l|}
\hline Treatments & $\mathbf{p H}$ in dough & $\mathbf{p H}$ in product \\
\hline 1 & $7.11 \mathrm{a} \pm 0.05$ & $5.32 \mathrm{c} \pm 0.04 \mathrm{~b}$ \\
\hline \multicolumn{3}{|c|}{ Blends from Corn } \\
\hline $\mathbf{2}$ & $7.16 \mathrm{a} \pm 0.02$ & $5.31 \mathrm{bc} \pm 0.03$ \\
\hline $\mathbf{3}$ & $7.09 \mathrm{a} \pm 0.02$ & $5.53 \mathrm{a} \pm 0.01$ \\
\hline $\mathbf{4}$ & $6.59 \mathrm{c} \pm 0.67$ & $5.44 \mathrm{~b} \pm 0.06$ \\
\hline \multicolumn{3}{|c|}{ Blends from Rice } \\
\hline $\mathbf{5}$ & $7.1 \mathrm{a} \pm 0.02$ & $5.25 \mathrm{c} \pm 0.06$ \\
\hline $\mathbf{6}$ & $7.11 \mathrm{a} \pm 0.02$ & $5.4 \mathrm{~b} \pm 0.04$ \\
\hline $\mathbf{7}$ & $6.87 \mathrm{~b} \pm 0.18$ & $5.39 \mathrm{~b} \pm 0.02$ \\
\hline L.S.D(0.05) & $\mathbf{0 . 1 2}$ & $\mathbf{0 . 0 7}$ \\
\hline
\end{tabular}

1) Cont.; blends from corn(2:Turmeric; 3: paprika; 4: Chili); blends from rice(5:Turmeric; 6: paprika; 7: Chili Means in the same column with different letters are significantly different $(p \leq 0.05)$.

Each mean value is followed by $\pm \mathrm{SE}$ (standard error). 
release $\mathrm{CO}_{2}$ gas from active yeast during baking temperature effect on $\mathrm{pH}$ in the final product. The results are in agreement with Johnson et al. (1980) who reported that an alkaline solution added to corn increased its yellowness, $\mathrm{pH}$, and flavor with simultaneous darkening.

\subsection{Sensory evaluation of pretzel produced from corn and rice blends}

In a preliminary study the sensory scores of the pretzel with $\mathrm{NaOH}, \mathrm{KOH}$ and $\mathrm{CaCO} 3$ solutions were tested. The $\mathrm{KOH}$ solution had a good effect on pretzel quality, thus, we selected $\mathrm{KOH}$ solution to produce pretzels with corn and rice flour which may be good for panelists.

Sensory quality attributes of pretzel expressed by panelists are presented in Table (5).

Significant differences were found in crispness, color, flavor, general appearance and overall scores for the produced samples. The crispness for all samples ranged between 9.5 and 8 , the highest value was noticed for control (1), then sample 3 (corn paprika pretzel) and sample 5 (rice turmeric pretzel), but the lowest value was for samples 2, 4 and 7. Concerning color, the panelists preferred the control sample followed by sample 3 then sample 2 and sample 5 . The flavor had the highest value for samples 1, 2, 3 and 4 (9), while the low value was for samples 5, 6 and 7 (8). The highest of overall score value was noticed in the control sample, then 2,3 and 5 samples without significant difference between them. The lowest value of overall score was noticed in sample 7 (rice chili pretzel). Yao et al. (2006) suggested that the color that developed on pretzel surface was not due to pigments present in the flour but was contributed by the reaction within or between the starch and protein hydrolysis derivatives during baking.

Table (5): Sensory evaluation of pretzel.

\begin{tabular}{|c|l|l|l|l|l|}
\hline Sample & \multicolumn{1}{|c|}{ Crispness } & \multicolumn{1}{|c|}{ Color } & Flavour & General appearances & Overall Score \\
\hline $\mathbf{1}$ & $9.5 \mathrm{a} \pm 0.03$ & $10.0 \mathrm{a} \pm 0.0$ & $9.0 \mathrm{a} \pm 0.0$ & $10.0 \mathrm{a} \pm 0.0$ & $38.5 \mathrm{a} \pm 0.32$ \\
\hline $\mathbf{7}$ & Blends from Corn & $34.92 \mathrm{~b} \pm 0.8$ \\
\hline $\mathbf{2}$ & $8.0 \mathrm{~d} \pm 0.54$ & $9.0 \mathrm{c} \pm 0.32$ & $9.0 \mathrm{a} \pm 0.32$ & $9.0 \mathrm{c} \pm 0.32$ & $35.41 \mathrm{~b} \pm 0.38$ \\
\hline $\mathbf{3}$ & $9.0 \mathrm{~b} \pm 0.0$ & $9.4 \mathrm{~b} \pm 0.38$ & $9.0 \mathrm{a} \pm 0.0$ & $8.0 \mathrm{~d} \pm 0.32$ & $34.0 \mathrm{c} \pm 0.32$ \\
\hline $\mathbf{4}$ & $8.0 \mathrm{~d} \pm 0.32$ & $8.0 \mathrm{e} \pm 0.0$ & $9.0 \mathrm{a} \pm .032$ & $9.0 \mathrm{c} \pm 0.32$ & $35.5 \mathrm{~b} \pm 0.32$ \\
\hline $\mathbf{7}$ & Blends from Rice & $33.92 \mathrm{c} \pm 0.2$ \\
\hline $\mathbf{5}$ & $9.0 \mathrm{~b} \pm 0.32$ & $9.0 \mathrm{c} \pm 0.0$ & $8.0 \mathrm{~b} \pm 0.32$ & $9.5 \mathrm{~b} \pm 0.32$ & $32.0 \mathrm{~d} \pm 0.45$ \\
\hline $\mathbf{6}$ & $8.5 \mathrm{c} \pm 0.32$ & $8.5 \mathrm{~d} \pm 0.32$ & $8.0 \mathrm{~b} \pm 0.0$ & $9.0 \mathrm{c} \pm 0.32$ & $\mathbf{0 . 5}$ \\
\hline
\end{tabular}

1) Cont.; blends from corn(2: Turmeric; 3: paprika; 4: Chili); blends from rice(5: Turmeric ; 6: paprika; 7: Chili

Means in the same column with different letters are significantly different $(p \leq 0.05)$. Each mean value is followed by \pm SE.

\subsection{Chemical composition of pretzel produced from corn and rice blends and different spices}

The data in Table (6) show that moisture content of all pretzel samples ranged from 4.18 $\%$ to $6.23 \%$ and the highest value was noticed for control sample. Such increment in moisture may be due to the high protein content in wheat flour which absorbed more water than starch. The protein in all pretzel samples ranged from $3.01 \%$ to $3.86 \%$. The highest value was noticed in the control sample but the lowest value was noticed in sample 6 (rice paprika pretzel). Significant difference in fat content was observed between pretzel samples and could be pronounced in sample 7 (rice chili pretzel) followed by sample 3 (corn paprika pretzel) and the lowest value was noticed in the control sample. Crude fiber significantly increased in samples 4 then sample 7 These samples contained corn chili flour and rice chili flour respectively which they had more fiber compared to wheat flour. There was little difference in total carbohydrates and calories among all pretzel samples as shown in Table (6).

According to FAO (1992), protein content of maize ranges from 8 to $11 \%$, a variety of snack foods widely consumed by Nigerians are made of low-protein cereals with lysine and tryptophan as limiting amino acids that are essential for human nutrition. Protein quality of rice surpasses that of wheat and corn while it is just inferior to oats. Also, rice protein is hypoallergenic and contains good quantity of lysine. Thus it may act as a suitable ingredient for infant food formulations while adding variety to the restricted diets of children with food allergies (Gurpreet and Sogi, 2007). Amino acid profile of rice protein was better than casein and 
Table (6): Chemical composition of pretzel on dry weight basis.

\begin{tabular}{|c|c|c|c|c|c|c|c|}
\hline Sample & Moisture \% & Protein \% & Ash \% & Fat $\%$ & $\begin{array}{c}\text { Crude } \\
\text { Fibre \% }\end{array}$ & $\begin{array}{c}\text { Total } \\
\text { Carbohydrates \% }\end{array}$ & $\begin{array}{c}\text { Calories } \\
\text { Kcal/100g }\end{array}$ \\
\hline 1 & $6.23 \mathrm{a} \pm 0.0$ & $\begin{array}{l}3.86 \mathrm{a} \\
\pm 0.01\end{array}$ & $\begin{array}{l}2.61 \mathrm{~b} \\
\pm 0.01\end{array}$ & $\begin{array}{l}4.81 \mathrm{~g} \\
\pm 0.01\end{array}$ & $0.77 \mathrm{f} \pm 0.0$ & $87.95 \mathrm{a} \pm 0.01$ & $\begin{array}{l}410.53 \mathrm{~d} \\
\pm 0.01\end{array}$ \\
\hline \multicolumn{8}{|c|}{ Blends from Corn } \\
\hline 2 & $4.87 \mathrm{~b} \pm 0.01$ & $\begin{array}{l}3.61 \mathrm{~b} \\
\pm 0.02\end{array}$ & $\begin{array}{l}1.67 \mathrm{e} \\
\pm 0.01\end{array}$ & $\begin{array}{l}5.59 \mathrm{~d} \\
\pm 0.0\end{array}$ & $1.91 \mathrm{~d} \pm 0.02$ & $87.22 \mathrm{a} \pm 0.04$ & $\begin{array}{l}413.63 \mathrm{c} \\
\pm 0.04\end{array}$ \\
\hline 3 & $4.48 \mathrm{f} \pm 0.0$ & $3.2 \mathrm{~d} \pm 0.1$ & $\begin{array}{l}2.8 \mathrm{a} \\
1 \pm 0.01\end{array}$ & $\begin{array}{l}7.11 \mathrm{~b} \\
\pm 0.0\end{array}$ & $2.14 \mathrm{c} \pm 0.01$ & $84.74 \mathrm{abc} \pm 0.1$ & $\begin{array}{l}415.75 \mathrm{~b} \\
\pm 0.1\end{array}$ \\
\hline 4 & $4.18 \mathrm{~g} \pm 0.0$ & $\begin{array}{l}3.54 \mathrm{~b} \\
\pm 0.02\end{array}$ & $\begin{array}{l}2.43 \mathrm{~d} \\
\pm 0.02 \\
\end{array}$ & $\begin{array}{l}6.31 \mathrm{c} \\
\pm 0.01 \\
\end{array}$ & $2.43 \mathrm{a} \pm 0.01$ & $85.29 a b \pm 1.4$ & $\begin{array}{l}412.11 \mathrm{~b} \\
\pm 1.4\end{array}$ \\
\hline \multicolumn{8}{|c|}{ Blends from Rice } \\
\hline 5 & $4.77 \mathrm{c} \pm 0.0$ & $\begin{array}{l}3.04 \mathrm{e} \\
\pm 0.07\end{array}$ & $\begin{array}{l}2.58 \mathrm{~b} \\
\pm 0.02\end{array}$ & $\begin{array}{l}5.44 \mathrm{f} \\
\pm 0.01\end{array}$ & $1.81 \mathrm{e} \pm 0.01$ & $87.13 \mathrm{a} \pm 0.07$ & $\begin{array}{l}409.64 \mathrm{~d} \\
\pm 0.07\end{array}$ \\
\hline 6 & $4.55 \mathrm{e} \pm 0.01$ & $\begin{array}{l}3.01 \mathrm{e} \\
\pm 0.02\end{array}$ & $\begin{array}{l}2.51 \mathrm{c} \\
\pm 0.01\end{array}$ & $\begin{array}{l}5.54 \mathrm{e} \\
\pm 0.01\end{array}$ & $2.15 \mathrm{c} \pm 0.14$ & $86.79 \mathrm{ab} \pm 0.06$ & $\begin{array}{l}409.06 \mathrm{~d} \\
\pm 0.06\end{array}$ \\
\hline 7 & $4.63 \mathrm{~d} \pm 00$ & $\begin{array}{l}3.44 \mathrm{c} \\
\pm 0.01\end{array}$ & $\begin{array}{l}2.50 \mathrm{c} \\
\pm 0.05\end{array}$ & $\begin{array}{l}7.17 \mathrm{a} \\
\pm 0.06\end{array}$ & $2.28 \mathrm{~b} \pm 0.03$ & $84.61 b c \pm 1.32$ & $\begin{array}{l}416.73 \mathrm{a} \\
\pm 1.32\end{array}$ \\
\hline LSD $5 \%$ & 0.01 & 0.08 & 0.03 & 0.04 & 0.09 & 1.17 & 1.17 \\
\hline
\end{tabular}

Means in the same column with different letters are significantly different $(p \leq 0.05)$.

Each mean value is followed by $\pm \mathrm{SE}$ (standard error).

soy protein isolate in fulfilling the amino acid requirements for 2-5 years old children (Wang et al., 1999).

3.6. Mineral content in pretzel produced from corn and rice blends and different spices

Table (7) revealed that the $\mathrm{Na}$ content in control pretzel (mg/100g), was low when using $\mathrm{KOH}$ caustic solution as compared with $\mathrm{NaOH}$ caustic solution as shown in the previous Table 2. Sodium recorded the highest value in corn turmeric pretzel (604.38); and the lowest value for corn paprika pretzel (503.29). Potassium has a role in heart health, so we prefer $\mathrm{KOH}$ caustic solution, potassium recorded the highest value in sample 7(rice chili pretzel). The data revealed that the $\mathrm{Ca}, \mathrm{Mg}$ and Fe content were high in corn paprika pretzel, then rice paprika pretzel. But the corn chili pretzel was the lowest sample in $\mathrm{Ca}$ and $\mathrm{Mg}$ content. Table (7) revealed that $\mathrm{Zn}$ content was almost the same in corn turmeric and rice chili pretzel. The corn chili pretzel was the lowest one in $\mathrm{Zn}$ content.

3.7. Keeping quality in pretzels produced from two blends (corn\& rice) and different spices

The moisture of final product, usually controlled at $2-4 \%$, for product quality and shelf life. Pretzels with too low moisture tend to be very fragile during packing and transportation, while pretzels high in moisture content become stale during storage and thus will not be accepted by consumers. The data presented in Table (8) showed hardness and water activity of pretzels made from two blends (corn\& rice) and different spices. The table indicated that there were no high change in value between zero and the end of storage period for hardness; where the highest value recorded was in blends of corn with chili spice for zero time and after storage (43.66\& $30.15 \mathrm{~N}$, respectively). Adhesiveness recorded high value after storage period for corn blends and the highest value was recorded for corn paprika pretzel $(7.50 \mathrm{mj})$. Moreover, the water activity recorded values between (0.428$0.502)$ in all treatments; where its data indicated that don't high change in value during storage period. Hence the highest value for water activity (0.502) recorded in sample turmeric rice after storage (3 months). These results may be due to the presence of amorphous granules starch keeping as low moisture content.

\subsection{The recommended dietary allowances for pretzels (RDA \%)}

The percentages of the recommended dietary allowances (RDA \%) are provided from $100 \mathrm{~g}$ of produced pretzels for children (7- 10 years) are shown in Table (9). It could be observed that all values of $\mathrm{RDA} \%$ for protein ranged from $10.75 \%$ to $13.79 \%$. This increase in $\mathrm{RDA} \%$ of protein in control pretzels may be due to high protein content in wheat flour than rice flour and corn flour. Meanwhile, RDA\% for calories was almost the same values. Concerning RDA\% for $\mathrm{Fe}$ and $\mathrm{Ca}$ was the highest values in corn pretzels than control and rice pretzels.

Among pretzels samples, corn or rice paprika caused an increase in RDA \% values of $\mathrm{Fe}, \mathrm{Ca}$ and $\mathrm{Mg}$, this increase in RDA\% may be due to 
Table (7): Mineral content in pretzel produced from corn and rice blends and different spices (mg/ $100 \mathrm{~g})$.

\begin{tabular}{|c|c|c|c|c|c|c|c|}
\hline Sample & Na & K & Ca & Mg & Zn & Fe \\
\hline 1 & 513.73 & 328.43 & 61.28 & 57.06 & 2.14 & 1.82 \\
\hline $\mathbf{7}$ & Blends from Corn \\
\hline $\mathbf{2}$ & 604.38 & 302.63 & 105.97 & 50.5 & 2.48 & 2.11 \\
\hline $\mathbf{3}$ & 503.29 & 357.86 & 149.17 & 107.82 & 1.85 & 2.41 \\
\hline $\mathbf{4}$ & 581.92 & 367.65 & 62.04 & 49.29 & 1.29 & 2.12 \\
\hline $\mathbf{7}$ & Blends from Rice \\
\hline $\mathbf{5}$ & 552.05 & 282.75 & 83.99 & 74.10 & 1.42 & 2.02 \\
\hline $\mathbf{6}$ & 548.95 & 392.45 & 124.3 & 102.38 & 1.56 & 2.32 \\
\hline $\mathbf{7}$ & 556.89 & 394.61 & 70.15 & 85.78 & 2.33 & 2.11 \\
\hline
\end{tabular}

1) Cont.; blends from corn(2: Turmeric; 3: paprika; 4: Chili); blends from rice(5: Turmeric; 6: paprika; 7: Chili

Table (8): Keeping quality for pretzel produced from corn and rice blends and different spices during storage periods (3 months).

\begin{tabular}{|c|c|c|c|c|c|c|c|}
\hline Samples & $\begin{array}{l}\text { Period } \\
\text { storage }\end{array}$ & Hardness(N) & Adhesiveness(mJ) & $\mathbf{a}_{W}$ in $\mathrm{Z} . T$ & $\dot{\mathbf{C}}$ & $\mathbf{a}_{W}$ in $\mathrm{As}$ & $\dot{\mathrm{C}}$ \\
\hline \multirow{2}{*}{ (Cont. KOH) } & Z.T & 31.46 & 0.00 & 0.430 & 22.12 & - & - \\
\hline & AS & 26.37 & 0.00 & - & - & 0.472 & 22.15 \\
\hline \multicolumn{8}{|c|}{ Blends from Corn } \\
\hline \multirow[b]{2}{*}{ Turmeric } & Z.T & 26.13 & 0.20 & 0.430 & 22.08 & - & - \\
\hline & $\mathbf{A S}$ & 22.19 & 0.40 & - & - & 0.474 & 22.08 \\
\hline \multirow[b]{2}{*}{ Paprika } & Z.T & 15.30 & 0.00 & 0.428 & 22.10 & - & - \\
\hline & $\mathbf{A S}$ & 15.30 & 7.50 & - & - & 0.483 & 22.06 \\
\hline \multirow[b]{2}{*}{ Chili } & Z.T & 43.66 & 0.10 & 0.428 & 22.13 & - & - \\
\hline & $\mathbf{A S}$ & 30.15 & 0.30 & - & - & 0.481 & 22.11 \\
\hline \multicolumn{8}{|c|}{ Blends from Rice } \\
\hline \multirow[t]{2}{*}{ Turmeric } & Z.T & 31.04 & 0.10 & 0.440 & 22.13 & - & - \\
\hline & $\mathbf{A S}$ & 21.59 & 0.30 & - & - & 0.502 & 22.13 \\
\hline \multirow[b]{2}{*}{ Paprika } & $\overline{\text { Z.T }}$ & 34.61 & 1.10 & 0.440 & 22.1 & - & - \\
\hline & $\mathbf{A S}$ & 26.63 & 0.80 & - & - & 0.495 & 22.08 \\
\hline \multirow[t]{2}{*}{ Chili } & Z.T & 23.58 & 0.00 & 0.433 & 22.12 & - & - \\
\hline & $\mathbf{A S}$ & 22.15 & 0.00 & - & - & 0.487 & 22.12 \\
\hline
\end{tabular}

Table (9): The recommended dietary allowances for pretzels (RDA \%).

\begin{tabular}{|c|c|c|c|c|c|}
\hline \multicolumn{6}{|c|}{ RDA \% } \\
\hline Samples & Protein $(28 g)$ & Calories(2000Kcal) & $\mathrm{Fe}(10 \mathrm{mg})$ & $\mathrm{Ca}(800 \mathrm{mg})$ & Mg(170mg) \\
\hline 1 & 13.79 & 20.52 & 18.2 & 7.66 & 33.56 \\
\hline \multicolumn{6}{|c|}{ Corn blends } \\
\hline 2 & 12.89 & 20.68 & 21.1 & 13.19 & 29.71 \\
\hline 3 & 11.43 & 20.79 & 24.1 & 18.65 & 63.42 \\
\hline 4 & 12.64 & 20.79 & 21.2 & 7.75 & 28.99 \\
\hline \multicolumn{6}{|c|}{ Rice blends } \\
\hline 5 & 10.86 & 20.48 & 20.2 & 10.5 & 43.59 \\
\hline 6 & 10.75 & 20.18 & 23.2 & 15.54 & 60.22 \\
\hline 7 & 12.29 & 20.99 & 21.1 & 8.77 & 50.46 \\
\hline \multicolumn{6}{|c|}{ 1) Cont.; blends from corn(2: Turmeric; 3: paprika; 4: Chili); blends from rice(5: Turmeric; 6: paprika; 7: Chili } \\
\hline \multicolumn{6}{|c|}{$\begin{array}{l}\text { According to: Food and Nutrition Board, Institute of Medicine and National Academies (2004). Dietary reference intakes } \\
\text { (DRIs). }\end{array}$} \\
\hline
\end{tabular}


the high content of $\mathrm{Fe}, \mathrm{Ca}$ and $\mathrm{Mg}$ of paprika than turmeric and chili.

\subsection{Economic evaluation for pretzel}

The production cost of $100 \mathrm{~g}$ pretzels ranged between 2.50 and 3 L.E. The cost of pretzels could be justified to consumer by increasing of their potential health benefit.

\section{Conclusions}

Pretzels are very popular snack food for children and adults, therefore the effect of different alkali caustic solution and supplementary mixture of corn and rice flour instead of wheat flour with different spices to produce healthy pretzels. The results concluded that $\mathrm{KOH}$ as caustic solution is preferred for cooking step instead of $\mathrm{NaOH}$ solution. Control and rice pretzels had the highest value for overall score with considerable significant protein. In addition to $\mathrm{KOH}$ solution had a good effect on pretzels quality such as color, sensory characteristics (texture and color).Also $\mathrm{KOH}$ solution caused improving storage period for 3 months. Water activity values indicated that the pretzels with $\mathrm{KOH}$ solution were in the safe range to 3 months.

\section{REFERENCES}

Abdelaal H. S. A. and Thilmany D. (2019). Grains production prospects and long run food security in Egypt. Sustainability, 11: 4457- 4474. http://dx. doi: 10.3390/Su11164457

AOAC (2005). Official Methods of Analysis Association of Official Analytical Chemists. 18th Edition, Washington DC. U.S.A.

Cepanec K., Sašenka V., Tanja C. and Jasmina R. (2017). Potassium chloride-based salt substitutes: a critical review with a focus on the patent literature. Comprehensive Reviews in Food Science and Food Safety, 16: $\quad 881-\quad 894 . \quad$ http://dx.doi.org/ 10.1111/1541-4337.12291

Cho S., Yoon S. H., Min J., Lee S., Tokar S.- O. L. and Seo H.S. (2014). Sensory characteristics of seolgitteok (Korean rice cake) in relation to the added levels of brown rice flour and sugar. J. Sens. Stud., 29 (5): 371-383.

Chuah A. M., Lee Y. C. Yamaguchi T., Takamura H., Yin L. J. and Matoba T. (2008). Effect of cooking on the antioxidant properties of colored peppers. Food Chem., 111: 20-28.
Doweidar M. M. M. (2006). Production and evaluation of gluten free cake. Bull. Fac. Agric. Cairo Univ., 57: 665- 684.

FAO (1992). Food and Agricultural Organization. Maize in Human Nutrition, UN Rome.

FAO/WHO (2004). Water and mineral requirements in human nutrition. $2^{\text {nd }}$ edition. USA. 230- 272.

Farquhar W. B., Edwards D. G., Jurkovitz C. T. and Weintraub W. S. (2015). Dietary Sodium and Health More Than Just Blood Pressure. The Amer. College Cardiol., 65 (10): 1042- 1050.

Giuffrida D., Dugo P., Torre G., Bignardi C., Cavazza A., Corradini- C. and Dugo G. ( 2013). Characterization of 12 Capsicum varieties by evaluation of their carotenoid profile and pungency determination. Food Chem., 140: 794-802.

Goel A. and Aggarwal B. B. (2010). Curcumin, the golden spice from Indian saffron is a chemo sensitizer and radio sensitizer for tumors and chemo protector and radio protector for normal orange. Nutri. and Cancer, 62:919-930.

Guil-Guerrero J. L., Martinez-Guirado C., Rebolloso-Fuentes M. and Carrique-Pérez A. (2006). Nutrient composition and antioxidant activity of 10 pepper (Capsicum annum) varieties. European Food. Technol., 224: 1-9.

Gurpreet K. C. and Sogi D. S. (2007). Functional properties of rice bran protein concentrates. J Food Eng., 79:592-597.

Johnson B. A., Rooney L. W. and Khan M. N. (1980). Tortilla-making characteristics of micronized sorghum and corn flours. J. Food Sci., 45(3):671- 674.

Khan, M. and Nowsad, A. K. M. A. (2012). Development of protein enriched shrimp crackers from shrimp shell wastes. J. Bangladesh Agri. Univ., 10(2): 367-374.

Meullenet Jf. C., Lyon B. G., John A. C., and Lyon C. E. (1998). Relation between sensory and instrumental texture profile attributes. J. sens. Stud., 13(1):77- 93. https://doi.org/10.1111/J.1745459x.1998.tb00076.x

Ott L. (1988). An introduction to statistical methods and data analysis. ( $3^{r d}$ ed.) PWSKent, Boston, M.A., USA.

Paykary M., Karim R., Saari N., Sulaiman R., Shekarforoush E. and Aghazadel M. (2016). Optimization of leavening agents 
in extruded gluten- free brewes' rice hard pretzel using response surface methodology. J. Food Proc. Eng., 39(6): 610- 624 doi:10.1111/jfpe.12254

Piga A., Catzeddu P., Farris S., Roggio T., Sanguinetti A. and Scano E. (2005). Texture evaluation of Amaretti cookies during storage. Euro. Food Res. and Tech., 221: 387-391.

Rooney J. and Rooney K. (2001). Pretzel stick snack item. U.S. patent, 6, 242, 021, June 5 (2001),USA.

Salgueiro M. J., Zubilage M.B., Lysionek A. C., Caro R. A., Weill R. and Baccio J. R. (2002). The role of Zinc in the growth and development of children. Nutri., 18: 510519.

Seetharaman K. (2014). Pretzel Production and Quality Control. In: "Bakery Products Science and Technology" Zhou, W.; Hui, Y. H. ;De Leyn, I. ;Pagani, M. A.; Rosell, C. M.; Selman, J. D. and Therdthai. N. (Eds). John Wiley \& Sons, Ltd. Pp.611618. www.wiley.com /wiley black well

Seetharaman K., Yao N. and Groff E.T. (2002). Quality assurance for hard pretzel production. Cereal Foods World, 46(8): 361-364.

Seetharaman K., Yao N. and Rout M. (2004). Role of water on pretzel dough development and final product quality. Cereal Chem., 81(3):336-40.

Wang M., Hettiarachchy N. S., Qi M., Burks W. and Siebenmogen T. (1999). Preparation and functional properties of rice bran protein isolate. J Agr. Food Chem., 47:411-416.

West G.T. and Christopher J.C. (2002). Method for making a shelf-stable soft pretzel. United States Patent, US 6,444,244 B1, Sep. 3, 2002(Patent).

WHO. (2012a). Guideline: sodium intake for adults and children. Geneva, Switzerland: World Health Organization.

WHO. (2012b). Guideline: potassium intake for adults and children. Geneva, Switzerland: World Health Organization.

Yao N., Richard O. - A., Zhu L. and Seetharaman K. (2006). Effect of alkali dipping on dough and final product quality. J. food sci., 71(3): 209- 215.

\section{أنتاج بريتزل صحى وأمن \\ أشجان محمد على - هلى حسن حافظ \\ قسم بحوث الخبز والعجائن ـ معهد بحوث تكنولوجيا الاغذية ـ مركز البحوث الزراعية ـ الجبزة - مصر .}

يعتبر البريتزل من المقرمشات الغذائية المحبية لمختلف الأعمار خاصة الأطفال. تم فى هذه الدراسة تقيبيم تأثير

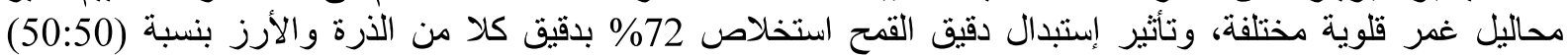

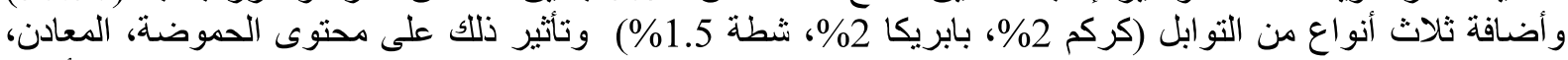

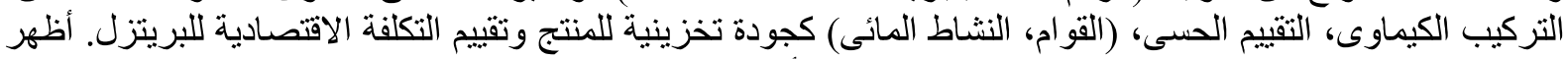

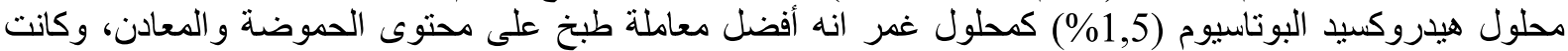

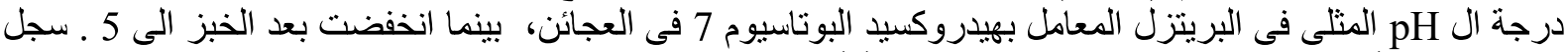

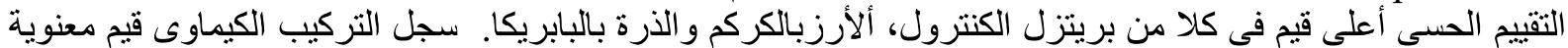

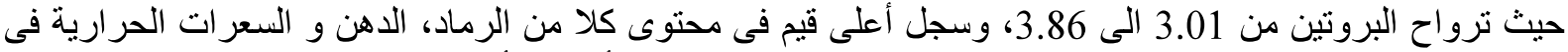

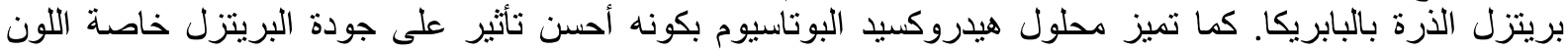

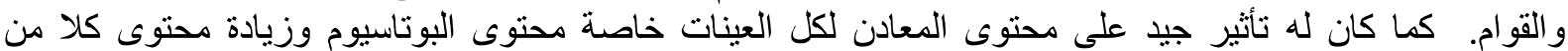

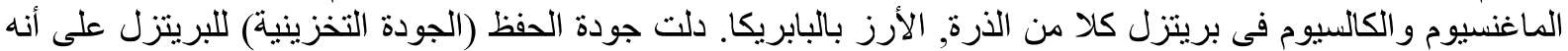

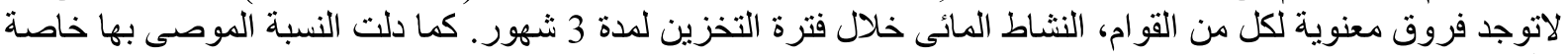

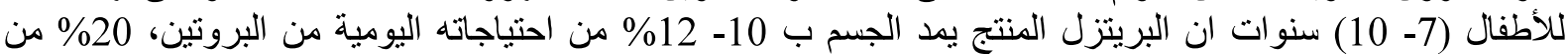

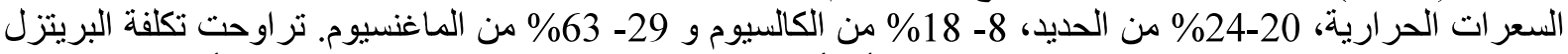

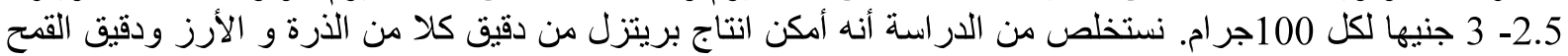

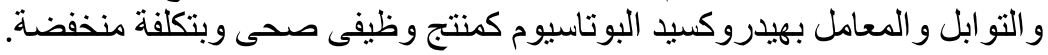

